\begin{tabular}{|c|c|c|c|c|}
\hline Share: Social Work Jurnal & VOLUME: 9 & NOMOR: 2 & HALAMAN: $130-141$ & $\begin{array}{c}\text { ISSN: } 2339-0042(\mathrm{p}) \\
\text { ISSN: } 2528-1577(e) \\
\text { Doi: } 10.24198 / \text { share.v9i2.21015 }\end{array}$ \\
\hline
\end{tabular}

\title{
STRATEGI PEMBERDAYAAN MASYARAKAT DALAM PELAKSANAAN PROGRAM DESA MANDI RI ENERGI
}

\author{
Ichda Umul Aisah', Herdis Herdiansyah ${ }^{2}$ \\ ${ }^{1}$ National Resilience Program, Graduate Program, Universitas Indonesia, Jakarta \\ ichda.aisah@yahoo.com \\ ${ }^{2}$ Sekolah I Imu Lingkungan Universitas Indonesia \\ herdis@ui.ac.id
}

\begin{abstract}
ABSTRAK
Energi merupakan komponen terpenting dalam rangka pembangunan suatu bangsa. Tidak dapat dipungkiri bahwa energi adalah penggerak aktivitas ekonomi dan sosial. Energi yang umumnya dipakai oleh negara di dunia adalah bahan bakar fosil baik dalam bentuk minyak maupun gas dan batu bara. Dewasa ini ketersediaan bahan bakar fosil terus menyusut, sementara kebutuhannya terus meningkat seiring dengan meningkatnya aktivitas sosial dan ekonomi. Tantangan terbesar kedepan adalah inovasi energi yang dapat menggantikan peran bahan bakar fosil. Penelitian ini bertujuan untuk menganalisis pemberdayaan dan menyusun strategi pelaksanaan program Desa Mandiri Energi di desa Haurngombong. Metode penelitian yang dilakukan adalah metode kualitatif dengan melakukan studi kasus melalui observasi dan wawancara mendalam pada masyarakat. Selain itu, dalam penelitian ini juga dilakukan analisis SWOT untuk menemukan strategi pelaksanaan program Desa Mandiri Energi di desa Haurngombong. Hasil penelitian menunjukkan bahwa energi alternatif yang diproduksi oleh masyarakat desa Haurngombong adalah biogas dari kotoran ternak sapi yang dikembangkan dengan melalui pemberdayaan masyarakat khususnya peternak sapi. Jenis konstruksi biogas yang dikembangkan adalah plastik, fiber, dan beton. Pembuatan biogas ini dipelopori oleh seorang peternak, pemanfaatan biogas hingga saat ini digunakan untuk biogas dan listrik. Untuk memastikan keberlanjutan produksi biogas ini diperlukan adanya ketersediaan bahan baku (kotoran sapi), peningkatkan mutu biogas, serta upaya pengembangan teknologi instalasi biogas, upaya penguatan anggota peternak dengan kelompok, upaya peningkatkan kerjasama dengan pihak luar program, upaya peningkatkan manajemen usaha ternak, upaya pemasyarakatkan biogas sebagai energi alternatif dan menjalin kerjasama jasa kredit perbankan guna pengembangan program. Namun demikian perlu adanya antisipasi kelemahan program yang telah berlangsung dengan optimalisasi jangkauan instalasi biogas, dan pemberian modal instalasi genset biogas.
\end{abstract}

Kata kunci: biogas, desa mandiri energi, pemberdayaan masyarakat, ternak 


\section{Pendahuluan}

Energi merupakan modal dasar pembangunan suatu negara. Energi memainkan peran strategis sebagai pilar penggerak ekonomi masyarakat, baik sebagai bahan baku sektor produksi maupun sebagai komoditas. Yusgiantoro menegaskan bahwa energi sangat berperan pada peningkatan perekonomian makro suatu negara (Yusgiantoro, 2000). Oleh karena itu, sudah menjadi kewajiban pemerintah untuk melindungi pengelolaan dan pemanfaatan energi sebagai suatu bentuk sumber daya kekayaan alam untuk dipergunakan bagi sebesar-besarnya kemakmuran masyarakat (Pasal 33 UUD RI, 1945).

Indonesia merupakan negara dengan potensi sumber daya energi yang sangat beragam, dengan sumber energi yang bersifat terbarukan (renewable recources) dan sumber energi yang bersifat tak terbarukan (unrenewable resources). Indonesia sebagai negara yang dilintasi oleh garis katulistiwa dan sekaligus negara tropis memiliki potensi sumberdaya energi alam yang sangat besar terutama energi cahaya dan panas bumi (Aiman et al., 2015). Berdasarkan Undang-Undang Nomor 30 Tahun 2007 tentang Energi, sumber energi terbarukan adalah sumber energi yang berkelanjutan jika dilakukan pengelolaan yang baik dalam pemanfaatannya. Lebih lanjut dijelaskan, bahwa sumber energi tak terbarukan adalah sumber energi yang akan habis jika dieksploitasi secara terus menerus.

Tantangan pengelolaan sumber energi di Indonesia adalah tingginya ketergantungan masyarakat atas pemanfaatan sumber daya energi tak terbarukan. Konsumsi energi final Indonesia terhitung hingga tahun 2011 didominasi oleh Bahan Bakar Minyak (BBM) dengan pangsa 32,7\% $(47,7 \%$, tanpa biomasa), diikuti oleh biomasa $25,1 \%$, batu bara $13 \%$, gas bumi $10,8 \%$, listrik $8,8 \%$, dan sisanya adalah elpiji, produk BBM lain, dan briket (Kementerian ESDM, 2012). Di sisi lain, data menunjukkan bahwa diperkirakan potensi minyak bumi Indonesia akan habis dalam jangka waktu 23 tahun mendatang, sementara potensi gas bumi dan batu bara masing-masing diperkirakan akan habis dalam jangka waktu 55 dan 83 tahun mendatang.

Dalam rangka mewujudkan ketahanan energi, salah satu pendekatan yang dilakukan oleh pemerintah adalah melalui Program Desa Mandiri Energi (DME). Berdasarkan Peraturan Menteri Energi dan Sumber Daya Mineral (ESDM) Nomor 32 Tahun 2008 tentang Penyediaan, Pemanfaatan dan
Tata Niaga Bahan Bakar Nabati (Biofuel) sebagai Bahan Bakar Lain, DME didefinisikan sebagai desa yang dapat memproduksikan energi berbasis Energi Baru dan Terbarukan untuk memenuhi dan menyediakan minimal $60 \%$ (enam puluh persen) kebutuhan energi bagi desa itu sendiri, energi tersebut termasuk Bahan Bakar Nabati (Biofuel) sebagai Bahan Bakar Lain (Permen ESDM No. 32 Tahun 2008). Dari segi ekonomi, DME bertujuan untuk menciptakan kegiatan ekonomi produktif, mengurangi kemiskinan, dan menambah lapangan kerja untuk mensubstitusi bahan bakar minyak sebagai upaya untuk mewujudkan ketahanan daerah (Qadi et al., 2018).

\section{Kajian Pusaka}

Pada hakikatnya pemberdayaan merupakan suatu proses depowerment dari suatu bentuk pemerintahan yang mutlak agar lebih manusiawi dan memperhatikan hak-hak manusia itu sendiri. Pemberdayaan masyarakat adalah pelibatan masyarakat dalam dalam keseluruhan proses, keterampilan analitis dan perencanaan pembangunan yang dimulai dari daerah tempat mereka berkarya sebagai partisipasi masyarakat dalam pembangunan nasional (Moeliono et al., 1994). Langkah pengikutsertaan masyarakat ini harus dipelopori atau di inisiasi oleh satu atau sekelompok orang yang memiliki kesadaran untuk mengembangkan potensi yang dimiliki masyarakat setempat. Sehingga masyarakat yang diberdayakan akan meningkat kompotensi dan/atau kemampuan serta ketrampilannya.

Pemberdayaan adalah suatu proses pendelegasian kekuasaan kepada masyarakat untuk berperan aktif dalam pembangunan. Lebih luas lagi memiliki pengertian hasil akhir dari proses pemberdayaan adalah beralihnya fungsi individu ditandai dengan adanya relasi antar subyek lama (pemerintah) dengan subyek baru atau yang semula obyek menjadi subyek baru. Dengan kata lain, proses pemberdayaan mengubah pola relasi menjadi relasi subyek dan subyek yang awalnya adalah keterkaitan antar subyek dan obyek (Prasetyo dan Hanifah, 2011). Dengan demikian kedepannya objek yang telah bertransformasi menjadi subyek akan memiliki kemampuan yang mendekati atau setara atau bahkan melebihi dari kemampuan yang dimiliki subyek awal. Segenap kemampuan yang dimiliki oleh subyek transformatif akan mendorong percepatan pembangunan baik ditingkat daerah maupun nasional. Keberhasilan transformasi wawasan dan kompetensi tercermin dari tingkat kemampuan dan daya tahan masyarakat dalam 


\begin{tabular}{|c|c|c|c|c|}
\hline Share: Social Work Jurnal & VOLUME: 9 & NOMOR: 2 & HALAMAN: $130-141$ & $\begin{array}{c}\text { ISSN: 2339-0042 (p) } \\
\text { ISSN: 2528-1577 (e) } \\
\text { Doi: } 10.24198 / \text { share.v9i2.21015 }\end{array}$ \\
\hline
\end{tabular}

menghadapi tantangan pembangunan. Pembangunan yang dimaksud adalah pembangunan fisik dan pembangunan manusia.

Pemberdayaan masyarakat desa bertujuan untuk meningkatkan kemampuan masyarakat pedesaan dengan jalan mengurangi intervensi pemerintah kepada masyarakat dalam berbagai program pembangunan dan memberikan kewenangan secara proporsional dalam pembangunan. Hal ini dilakukan sebagai upaya memampukan dan memandirikan masyarakat desa dalam pembangunan. Kemandirian masyarakat menjadi bagian penting dalam memajukan suatu bangsa (Nejat et al., 2015). Kemandirian tersebut mencakup hal yang sangat luas baik dalam konteks pangan maupun energi. Pada hakikatnya pemberdayaan merupakan suatu proses depowerment dari suatu bentuk pemerintahan yang mutlak agar lebih manusiawi dan memperhatikan hak-hak manusia itu sendiri.

Secara konseptual pemberdayaan merupakan proses pemberkuasaan dan berkaitan erat dengan kekuasaan. Suharto (1997) menjelaskan bahwa proses pemberdayaan akan sangat mungkin terjadi bila:

1. Kekuasaan dapat berubah, jika tidak dengan cara apapun proses pemberdayaan akan sangat tidak mungkin dilakukan;

2. Kekuasaan dapat diperluas, hal ini ditekankan pada pengertian kekuasaan yang tidak statis namun dinamis.

Sehingga pemberdayaan diperuntukan untuk:

a) Memenuhi kebutuhan dasar orang/atau kelompok rentan sehingga orang/atau kelompok tersebut memiliki kebebasan (freedom) dalam arti tidak hanya kebebasan untuk mengemukakan pendapat tetapi juga bebas dari kelaparan, penyakit, dan kebodohan;

b) Memperoleh sumber-sumber produktif yang memungkinkan orang/atau kelompok tersebut dapat meningkatkan pendapatan dan perolehan barang dan jasa yang diperlukan.

Lebih lanjut Ife dan Tesoriero (2008) menegaskan pemberdayaan masyarakat memuat dua pengertian utama yaitu kekuasaan dan kelompok lemah. Kekuasaan disini bukan hanya diartikan dalam arti sempit namun kekuasan atas hal-hal berikut:

1. Pilihan-pilihan personal dan kesempatankesempatan hidup: kemampuan dalam rangka membuat keputusan tentang gaya hidup, tempat tinggal dan pekerjaan;
2. Pendefinisian kebutuhan: kemampuan dalam rangka menentukan kebutuhan selaras dengan aspirasi dan keinginannya;

3. I de atau gagasan: kemampuan dalam rangka mengekspresikan dan menyumbang gagasan dalam forum diskusi secara bebas dan tanpa tekanan;

4. Lembaga-lembaga: kemampuan dalam rangka menjangkau, menggunakan dan mempengaruhi pranata-pranata masyarakat;

5. Sumber-sumber: kemampuan memonilisasi sumber-sumber formal, informal, kemasyarakatan;

6. Aktivitas ekonomi: kemampuan dalam rangka pemanfaatan dan pengelolaan mekanisme produksi, distribusi dan pertukaran barang dan jasa;

7. Reproduksi: kemampuan yang berkaitan dengan proses kelahiran, merawat anak, dan pendidikan untuk anak.

Berdasarkan uraian diatas melalui pemberdayaan masyarakat memberikan kesempatan kepada masyarakat untuk berpartisipasi dalam menentukan sendiri strategi pendekatan pembangunan.

Pemberdayaan masyarakat desa bertujuan untuk meningkatkan kemampuan masyarakat pedesaan dengan jalan mengurangi intervensi pemerintah kepada masyarakat dalam berbagai program pembangunan dan memberikan kewenangan secara proporsional dalam pembangunan. Hal ini dilakukan sebagai upaya memampukan dan memandirikan masyarakat desa dalam pembangunan.

Pencanangan Program DME ditujukan untuk membangun kemandirian energi masyarakat dengan mengembangkan sumber energi alternatif biogas dari limbah kotoran sapi perah. Program DME mengedepankan aspek pemberdayaan masyarakat pedesaan khususnya pemberdayaan komunitas peternak. Program ini dirancang dengan melibatkan masyarakat secara umum dan komunitas peternak secara khusus dalam keseluruhan proses penyusunan dan pelaksanaan program. Masyarakat dan komunitas peternak diberikan bekal pengetahuan dan keahlian melalui sosialisasi dan pelatihan agar keduanya memiliki keterampilan untuk mengelola instalasi biogas. Biogas sebagai bahan bakar terbarukan menjadi salah satu solusi energi masa depan. Diharapkan dengan keterampilan yang mereka miliki, keduanya dapat memanfaatkan biogas secara mandiri dan mengembangkan sektor produktif 


\begin{tabular}{|c|c|c|c|c|}
\hline Share: Social Work Jurnal & VOLUME: 9 & NOMOR: 2 & HALAMAN: $130-141$ & $\begin{array}{c}\text { ISSN: 2339-0042 (p) } \\
\text { ISSN: 2528-1577 (e) } \\
\text { Doi: } 10.24198 / \text { share.v9i2.21015 }\end{array}$ \\
\hline
\end{tabular}

lainnya hingga tercipta peningkatan kesejahteraan masyarakat desa pada masa yang akan datang.

Program DME dikembangkan dengan mengusung konsep pemanfaatan energi terbarukan dengan memperhatikan adanya potensi energi setempat sebagai energi alternatif yang dapat digunakan bagi pemenuhan kebutuhan energi dan kegiatan yang bersifat produktif masyarakat desa. DME didefinisikan sebagai desa yang masyarakatnya memiliki kemampuan untuk memenuhi lebih dari $60 \%$ kebutuhan energi listrik serta bahan bakar dari sumber energi terbarukan yang dihasilkan dengan memanfaatkan penggunaan potensi sumber daya yang ada. Hal tersebut menjadi sebuah terobosan sekaligus peluang untuk memadukan atau mengkombinasikan sumber energi alternatif yang dikelola dengan prinsip teknologi modern dengan mengadopsi kearifan lokal (Wang dan Jiang, 2017). Tujuan DME adalah untuk meningkatkan produktivitas, kesempatan kerja dan kesejahteraan masyarakat pada umumnya dengan adanya penyediaan energi yang terjangkau dan berkelanjutan (Pemerintah Desa Haurngombong, 2011). Kedepannya, pengembangan DME dimaksudkan untuk mendorong pengembangan kegiatan ekonomi pedesaan. Pemanfaatan energi yang tepat dan pengembangan DME yang signifikan akan mampu meningkatkan pemberdayaan ekonomi masyarakat (Sugiono, 2012).

Dalam rangka optimalisasi pencapaian tujuan Program DME, perlu adanya perumusan strategi yang tepat dalam kebijakan Program DME. Kata strategi awalnya berasal dari bahasa Yunani kuno yang berarti "Seni berperang" atau kepemimpinan dalam hal yang berhubungan dengan militer. Suatu strategi memiliki dasar-dasar atau skema untuk mencapai hal atau sasaran yang akan dituju. Strategi menurut Bryson didefinisikan sebagai suatu pola tujuan, kebijakan, program, tindakan, keputusan, atau alokasi sumberdaya yang memperlihatkan jati diri dari suatu organisasi, halhal yang dikerjakannya, dan alasan mengerjakan hal tersebut (Bryson, 1999).. Sebagai tambahan, strategi sebagai perluasan dari suatu tugas untuk menghubungan antara organisasi yang ada dengan lingkungannya (Hendra, 2014). Strategi yang bekerja efektif adalah yang dapat membuat kekuatan dan peluang suatu perusahaan menjadi maksimal (Pearce dan Robinson, 1994). Peluang dan ancaman secara sistematis dibandingkan dengan kekuatan dan kelemahan dengan pendekatan yang terstruktur (Nasdian, 2006).
Dari beberapa konsep ketahanan energi diatas dapat disimpulkan bahwa ketahanan energi secara garis besar mencakup 3 (tiga) aspek yaitu ketersediaan (availability), keterjangkauan (accessibility) dan akseptabilitas harga (Aly et al., 2017). Perumusan strategi dilakukan untuk menjamin ketepatan pencapaian sasaran. Suatu rancangan strategi dapat dibuat untuk menutup kesenjangan dalam mencapai sasaran. Berkenaan dengan perumusan strategi maka organisasi dapat mengkaji faktor-faktor apa saja yang dapat mempengaruhi melalui matriks kekuatan, kelemahan, peluang, ancaman (SWOT).

Ketersediaan energi yang berada pada konteks ketahanan energi dapat diartikan sejauhmana faktor-faktor produksi energi tersedia guna mencukupi kebutuhan untuk masyarakat. Aspek lain yang harus diperhatikan dalam rangka mengukur ketahanan energi nasional adalah aspek keterjangkauan. Keterjangkauan dalam arti tersedianya infrastruktur energi yang menjangkau segenap lapisan masyarakat diterima oleh masyarakat. Aspek akseptabilitas harga mengukur sejauhmana sumber daya energi dapat dijangkau masyarakat dalam konteks harga keekonomian sehingga dapat meningkatkan produktivitas masyarakat. Dalam penelitian ini, peneliti menganalisis ketahanan energi Program DME dengan mengacu kepada ketiga aspek tersebut.

Analisis kebijakan pada pelaksanaan Program DME dilakukan dengan cara menghubungkan tujuan kebijakan dengan realisasi hasil program kegiatan dilapangan. Analisis kebijakan memungkinkan masyarakat dan para pemangku kepentingan untuk mengetahui sejauhmana pilihan kebijakan yang diambil terealisasikan dan sejauhmana kesesuaian pilihan kebijakan dengan maksud pencapaian tujuan program. Melalui hal tersebut pelaksanaan program DME dapat dikontrol dan dievaluasi secara komprehensif untuk meningkatkan kualitasnya. Oleh karena itu, analisis kebijakan menjadi hal yang harus dilakukan untuk memastikan suatu program layak dilakukan atau tidak dalam rangka mewujudkan kesejahteraan masyarakat.

\section{Metode}

Dalam penelitian ini pendekatan yang digunakan adalah pendekatan kualitatif sehingga penggunaan pendekatan kualitatif dalam penelitian ini adalah dengan cara melakukan penyesuaian antara realita empirik dengan teori yang ada dengan penggunaan metode deskriptif (Moleong, 2004). Jenis riset yang digunakan pada penelitian artikel 


\begin{tabular}{|c|c|c|c|c|}
\hline Share: Social Work Jurnal & VOLUME: 9 & NOMOR: 2 & HALAMAN: $130-141$ & $\begin{array}{c}\text { ISSN: 2339-0042 (p) } \\
\text { ISSN: 2528-1577 (e) } \\
\text { Doi: } 10.24198 / \text { share.v9i2.21015 }\end{array}$ \\
\hline
\end{tabular}

ini adalah studi kasus. Penelitian ini dilakukan untuk memperoleh gambaran yang mendalam mengenai model pendekatan pemberdayaan masyarakat yang diterapkan dalam pelaksanaan Program DME di Desa Haurngombong. Selain itu, penelitian ini dilakukan untuk menganalisis strategi pelaksanaan Program DME dan keterkaitannya dengan ketahanan energi di Desa Haurngombong. Data yang digunakan pada riset ini ada dua yaitu data primer dan data skunder. Data primer adalah data yang didapat langsung dari hasil observasi (pengamatan langsung) dan wawancara mendalam. Penulis menggunakan data ini untuk mendapatkan informasi lansung tentang pemberdayaan masyarakat dalam pelaksanaan Program DME dalam kaitannya dengan ketahanan energi di Desa Haurngembong.

Data sekunder adalah data yang diperoleh melalui sumber bacaan dan berbagai macam sumber lainnya seperti modul pelatihan, naskah perundang-undangan dan juga dokumen-dokumen resmi dari berbagai sumber maupun instansi pemerintah. Data sekunder juga dapat berupa majalah, buletin, publikasi dari berbagai organisasi, hasil-hasil studi, hasil survei, studi histories, dan sebagainya. Penulis menggunakan data sekunder dengan alasan untuk memberi penguatan pada temuan serta melengkapi informasi yang telah diperoleh dari observasi dan wawancara.

Teknik pengumpulan data dalam penelitian ini adalah observasi dan wawancara. Pada penelitian ini, peneliti melakukan observasi terhadap penyelenggaraan Program DME di Haurngombong. Kegiatan observasi yang dilakukan antara lain observasi ke rumah peternak sapi perah untuk meninjau langsung penggunaan biogas dalam rumah tangga dan observasi ke kandang sapi perah untuk mengamati proses pengoperasian instalasi biogas yang pada umumnya terletak berdampingan dengan kandang. Wawancara memungkinkan peneliti untuk mengumpulkan beragam data dari informan yang dijadikan sampel penelitian. Pewawancara memiliki kesempatan untuk menelusur topik yang dianggap menarik dengan mengajukan beberapa pertanyaan tambahan. Selain itu, analisis data juga dilakukan dengan menggunakan analisis SWOT.

Analisis SWOT merupakan analisis terhadap situasi dan kondisi yang berpengaruh, yang terdapat di lingkungan internal maupun lingkungan eksternal kebijakan. Analisis tersebut didasarkan pada logika yang dapat membuat kekuatan (strengths) menjadi maksimal, dan peluang (opportunities), namun pada waktu yang bersamaan dapat mengurangi kelemahan (weaknesses) dan ancaman (threats). Dengan begini suatu organisasi mampu memandang kekuatan, kelemahan, peluang dan ancaman sebagai suatu kesatuan yang integral untuk mengetahui potensi isu-isu strategis dan yang kemungkinan akan dihadapi dalam penyelenggaraan organisasi.

\begin{tabular}{|c|c|c|}
\hline $\begin{array}{ll}\text { Faktor } \\
\text { Eksternal }\end{array}$ & Kekuatan (S) & Kelemahan (W) \\
\hline Peluang (O) & $\begin{array}{c}\text { Strategi SO } \\
\text { Ciptakan strategi yang } \\
\text { menggunakan kekuatan } \\
\text { untuk memanfaatkan } \\
\text { peluang }\end{array}$ & $\begin{array}{c}\text { Strategi WO } \\
\text { Ciptakan strategi yang } \\
\text { meminimalkan } \\
\text { kelemahan untuk } \\
\text { memanfaatkan peluang }\end{array}$ \\
\hline Ancaman (T) & $\begin{array}{c}\text { Strategi ST } \\
\text { Ciptakan strategi yang } \\
\text { menggunakan kekuatan } \\
\text { untuk mengatasi ancaman }\end{array}$ & $\begin{array}{c}\text { Strategi WT } \\
\text { Ciptakan strategi yang } \\
\text { meminimalkan } \\
\text { kelemahan dan } \\
\text { menghindari ancaman }\end{array}$ \\
\hline
\end{tabular}

Gambar 1. Matriks Analisis SWOT

Sumber: Pearce dan Robinson, 1994

Matriks SWOT diatas menunjukan bahwa terdapat 4 (empat) strategi lain sebagai hasil dari analisis SWOT yaitu: pertama, strategi SO yaitu suatu strategi yang dibuat berdasarkan pemikiran yang memanfaatkan seluruh kekuatan untuk memperoleh dan memanfaatkan peluang secara maksimal. Kedua, strategi ST yaitu strategi dalam menggunakan kekuatan yang dimiliki untuk mengatasi ancaman. Ketiga, strategi WO yaitu strategi ini diterapkan dengan memanfaatkan peluang yang ada dengan cara meminimalisir kelemahan yang ditemukan. Keempat, strategi WT didasarkan pada kegiatan usaha meminimalisir kelemahan yang ditemukan serta menjauhi ancaman (Rangkuti, 2001). Dalam rangka merumuskan kebijakan yang cocok untuk menentukan strategi pelaksanaan Program DME maka diperlukan analisa kondisi kekuatan, kelemahan sebagai faktor internal serta peluang dan ancaman sebagai faktor eksternal yang mempengaruhi kelancaran pelaksanaan program. 


\section{Hasil dan Pembahasan}

\subsection{Kronologis Program Desa Mandiri Energi di Desa Haurngombong}

Cikal bakal Program DME di Desa Haurngombong bermula dari inisiatif Bapak Adang SP sebagai Kepala Desa dan Bapak Komar Purnama sebagai anggota Kelompok Ternak Harapan Sawargi, untuk mengembangkan teknologi biogas sederhana guna mengatasi keresahan masyarakat atas kondisi sanitasi lingkungan yang buruk akibat limbah kotoran sapi perah. Belum adanya pengelolaan pembuangan limbah ternak baik mengakibatkan pencemaran sumber air bersih setempat dan menimbulkan bau tidak sedap. Bapak Komar mulai merakit instalasi biogas sederhana pada tahun 2003 yaitu dengan menggunakan plastik sebagai bahan dasar penampung gas, selang dan kaleng bekas sebagai kompornya.

Pengembangan biogas sederhana tersebut tidak langsung diterima oleh masyarakat Desa Haurngombong. Mayoritas masyarakat desa saat itu memanfaatkan minyak tanah, kayu bakar dan sekam sebagai sumber daya energi utama rumah tangga. Keseluruhan komponen tersebut dapat dikatakan sebagai bahan bakar kontemporer. Bahan bakar tersebut menjadi pilihan utama masyarakat pada umumnya di Indonesia pada beberapa dekade lalu sekalipun saat ini masih ada yang menggunakan. Jika diteruskan penggunaan bahan bakar tersebut akan memicu eksploitasi terhadap lingkungan yang berlebihan, sehingga diperlokan adanya bahan bakar alternatif (Wei et al., 2014). Adanya beban biaya instalasi dan ketersediaan energi lain yang lebih murah menjadi alasan masyarakat Desa Haurngombong tidak tertarik dengan biogas. Hal tersebut tidak mematahkan semangat Bapak Komar untuk mengembangkan biogas dikalangan kelompok ternak dengan bimbingan Kepala Desa Haurngombong.

Harga minyak tanah yang membumbung tinggi hingga mencapai Rp. 8.000 per liter pada tahun 2007 mendorong warga masyarakat Desa Haurngombong untuk mencari energi alternatif lain. Penggunaan kayu bakar yang terus menerus telah menyebabkan penggundulan hutan dan mengancam timbulnya erosi serta pengurangan cadangan air tanah. Tingginya harga minyak tanah dan berkurangnya ketersediaan kayu bakar mendorong warga khususnya para peternak untuk mencoba memanfaatkan biogas sebagai sumber energi baru. Melihat respon yang positif dari para warga, Bapak Adang sebagai Kepala Desa menetapkan Surat Keputusan Nomor
141/05/SK/DS/2007, mencanangkan Desa Haurngombong sebagai Desa Mandiri Energi.

Tujuan dari Program DME yang ada pada Desa Haurngombong adalah untuk menambah ketersediaan energi alternatif berbasis biogas sapi perah untuk peternak dan juga anggota masyarakat yang ada disentra peternak sapi perah. Program ini diharapkan dapat menjadi program yang murah, mudah dan ramah lingkungan dalam rangka mewujudkan keswadayaan energi bahan bakar sehingga tidak tergantung kepada gas elpiji, minyak tanah, maupun listrik PLN; mengurangi jumlah rumah tangga miskin, mengembangkan ekonomi produktif (agroindustri) dan sebagai program pemerintah menjadi seiring sejalan dengan kegiatan di masyarakat. Hasil yang diharapkan dari akhir program DME ini adalah dengan terpasangnya instalasi biogas secara optimal yang digunakan oleh para keluarga peternak dan juga keluarga non peternak yang dapat memberikan kontribusi secara nyata untuk penghematan energi minyak dan pada akhirnya mengurangi pengeluaran pada rumah tangga dan dapat menambah kesejahteraan keluarga maupun masyarakat desa. Adapun sasaran dari program ini adalah seluruh peternak sapi perah dan juga masyarakat yang lain disentra peternak sapi perah Desa Haurngombong.

Dalam rangka mewujudkan tujuan Program DME, pemerintah desa bekerjasama dengan LiBEC UNPAD untuk mengembangkan teknologi biogas dan melakukan pembinaan pada kelompok ternak dan warga desa. Teknologi biogas awal yang dikembangkan masih pada penggunaan biogas sebagai alternatif pengganti penggunaan minyak tanah dan gas elpiji. Jumlah instalasi biogas di Desa Haurngombong pada akhir 2007 mencapai 60 unit.

PLN DJ BB melihat adanya potensi keberhasilan pengembangan energi biogas di Desa Haurngombong pada tahun 2008. Akses masyarakat desa terhadap jaringan listrik PLN saat itu masih sangat terbatas. Rendahnya kemampuan daya beli masyarakat dan kondisi geografis desa yang berbukit-bukit menyulitkan pihak PLN untuk membangun infrastruktur jaringan listrik di Haurngombong. Keterbatasan akses menjadi persoalan utama untuk memberikan layanan optimal bagi konsumen. Hal ini harus dipahami bahwa risiko untuk mengoptimalkan pelayanan di daerah pelosok sangat besar. PLN DJ BB menetapkan Desa Haurngombong sebagai desa binaan PLN pada tahun 2008 dengan memberikan dukungan dana dan supervisi Program DME. Pada 


\begin{tabular}{|c|c|c|c|c|}
\hline Share: Social Work Jurnal & VOLUME: 9 & NOMOR: 2 & HALAMAN: 130 - 141 & $\begin{array}{c}\text { ISSN: } 2339-0042(p) \\
\text { ISSN: } 2528-1577(e) \\
\text { Doi: } 10.24198 / \text { share.v9i2.21015 }\end{array}$ \\
\hline
\end{tabular}

awal tahun 2008, kelompok ternak dan LiBEC UNPAD telah berhasil mengembangkan instalasi biogas berbahan bakar fiber. Pada tahun ini pula, PLN DJBB mendorong keduanya untuk mengembangkan teknologi instalasi biogas yang mampu menghasilkan listrik. Pada tanggal 23 - 26 November 2008, Desa Haurngombong berhasil memenangkan Lomba Desa Mandiri Energi yang diselenggarakan oleh Kementerian Koordinator Bidang Perekonomian RI di Bali. Desa Haurngombong dinobatkan sebagai Desa Terbaik Nasional dalam bidang energi.

Program DME yang diinisiasi oleh Kepala desa dan kelompok ternak sapi perah Desa Haurngombong ini menarik perhatian Kementerian ESDM. Program ini sejalan dengan Program DME yang merupakan bagian dari kebijakan diversifikasi energi Kementerian ESDM. Berdasarkan Ketentuan Umum Peraturan Menteri ESDM Nomor 30 Tahun 2008 tentang Penyediaan, Pemanfaatan Dan Tata Niaga Bahan Bakar Nabati (Biofuel) Sebagai Bahan Bakar Lain, yang dimaksud dengan DME adalah desa yang dapat memproduksikan energi berbasis Energi Baru dan Terbarukan, termasuk Bahan Bakar Nabati (Biofuel) sebagai Bahan Bakar Lain, untuk memenuhi dan menyediakan minimal $60 \%$ (enam puluh persen) kebutuhan energi bagi desa itu sendiri. Kedua program tersebut bertujuan untuk mewujudkan ketahanan energi pedesaan melalui pendayagunaan potensi sumber daya setempat.

Berdasarkan Surat Keputusan Desa Haurngombong Nomor 141/05/SK/DS/2007 tertanggal 7 Oktober 2007 tentang Desa Haurngombong sebagai Desa Mandiri Energi, pemerintah desa membentuk panitia pembangunan instalasi biogas Desa Haurngombong, Kecamatan Pamulihan, Kabupaten Sumedang. Panitia pembangunan instalasi biogas Desa Haurngombong secara struktural menyelenggarakan kegiatan dibawah koordinasi pemerintah desa.

Panitia pembangunan instalasi biogas Desa Haurngombong pada awal pembentukannya diketuai oleh Bapak Komar Purnama dan beranggotakan para pengurus kelompok ternak. Fungsi utama panitia pembangunan instalasi biogas adalah melakukan pemberdayaan kepada masyarakat khususnya keluarga peternak dalam mekanisme pengelolaan limbah kotoran sapi menjadi biogas. Fungsi panitia pembangunan instalasi biogas Desa Haurngombong kini melebur dalam fungsi organisasi ketiga kelompok ternak Desa Haurngombong.

Dalam menjalankan fungsi utamanya, para pengurus kelompok ternak memberikan pemahaman dan pelatihan kepada masyarakat termasuk anggota kelompok ternak secara khusus mengenai tata cara pembuatan, pemanfaatan dan pemeliharaan instalasi biogas atau biodigester. Pada umumnya instalasi biogas di Desa Haurngombong dilengkapi dengan 2 (dua) tabung penyimpanan gas. Tabung yang pertama dimanfaatkan untuk energi gas pengganti elpiji dan minyak tanah untuk memasak dan tabung kedua digunakan sebagai energi listrik yang disalurkan melalui genset.

Setidaknya ada 3 (tiga) jenis instalasi biogas di Desa Haurngombong, yaitu instalasi biogas dengan konstruksi plastik, instalasi biogas dengan konstruksi fiber dan instalasi biogas dengan konstruksi beton (Tabel 1). Mayoritas peternak di Desa Haurngombong saat ini menggunakan instalasi biogas berbahan beton yang didanai dari bantuan Kementerian ESDM pada tahun 2010. J umlah instsalasi biogas berbahan beton mencapai 105 unit sedangkan instalasi dengan konstruksi fiber berjumlah 80 unit dan sebanyak 35 unit lainnya berbahan plastik. Ketiga instalasi biogas tersebut memiliki keunggulan dan kelemahannya masing-masing.

Tabel 1. Perbandingan Konstruksi Instalasi Biogas Di Desa Haurngombong

\begin{tabular}{|c|c|c|c|c|}
\hline $\begin{array}{l}\text { Jenis } \\
\text { Konstruksi }\end{array}$ & $\begin{array}{l}\text { Tabung } \\
\text { Penyimpanan } \\
\text { Gas }\end{array}$ & Pipa Saluran & Keunggulan & Kekurangan \\
\hline Plastik & Plastik & $\begin{array}{l}\text { Selang } \\
\text { plastik }\end{array}$ & $\begin{array}{l}\text { 1. Konstruksi } \\
\text { sederhana } \\
\text { 2. Waktu pasang } \\
\text { singkat } \\
\text { 3. Dapat dipindah- } \\
\text { pindah } \\
\text { 4. Mudah diperbaiki } \\
\text { 5. Biaya pasang } \\
\text { murah }\end{array}$ & $\begin{array}{l}\text { 1. Cukup riskan } \\
\text { untuk } \\
\text { dipindahkan } \\
\text { 2. Tidak tahan lama }\end{array}$ \\
\hline Fiber & Plastik & $\begin{array}{l}\text { Selang } \\
\text { plastik/pipa } \\
\text { paralon }\end{array}$ & $\begin{array}{l}\text { 1. Waktu pasang } \\
\text { singkat } \\
\text { 2. Dapat dipindah- } \\
\text { pindah } \\
\text { 3. Mudah diperbaiki } \\
\text { 4. Daya tahan lama }\end{array}$ & $\begin{array}{l}\text { Biaya konstruksi } \\
\text { agak mahal }\end{array}$ \\
\hline Beton & $\begin{array}{l}\text { Tanpa alat } \\
\text { penampung }\end{array}$ & Pipa paralon & Daya tahan lama & $\begin{array}{l}\text { 1. Pemasangan } \\
\text { butuh waktu } \\
\text { lama dapat } \\
\text { 2. Tidak dipindah- } \\
\text { pindahkan } \\
\text { 3. Sulit diperbaiki } \\
\text { 4. Biaya konstruksi } \\
\text { mahal }\end{array}$ \\
\hline
\end{tabular}




\begin{tabular}{|c|c|c|c|c|}
\hline Share: Social Work Jurnal & VOLUME: 9 & NOMOR: 2 & HALAMAN: $130-141$ & $\begin{array}{c}\text { ISSN: 2339-0042 (p) } \\
\text { ISSN: 2528-1577 (e) } \\
\text { Doi: } 10.24198 / \text { share.v9i2.21015 }\end{array}$ \\
\hline
\end{tabular}

Konstruksi instalasi biogas berbahan plastik sangat sederhana, murah dan mudah untuk dibuat. Konstruksi jenis ini memiliki kekurangan dari segi daya tahan penggunaan. Konstruksi plastik sangat rentan terhadap kebocoran. Konstuksi biogas berbahan fiber dinilai memiliki daya tahan yang lebih lama. Disamping waktu pembuatannya yang cepat dan mudah diperbaiki, konstruksi ini memiliki kekurangan yakni biaya instalasinya yang agak mahal. Berbeda dengan dua instalasi biogas sebelumnya, instalasi biogas berbahan beton memiliki daya tahan yang paling lama akan tetapi instalasi biogas jenis ini juga membutuhkan dana pembangunan instalasi yang jauh lebih besar.

Mayoritas masyarakat Desa Haurngombong mengelola ketiga instalasi biogas diatas untuk menghasilkan energi biogas sebagai pengganti kayu bakar, minyak tanah dan elpiji. Adapun pemanfaatan energi biogas dengan menggunakan genset sebagai pembangkit energi listrik masih sangat terbatas karena mahalnya alat genset yang dibutuhkan. Hal tersebut secara tidak langsung menjadi tekanan bagi masyarakat untuk menjawab tantangan kemandirian dan ketahanan energi.

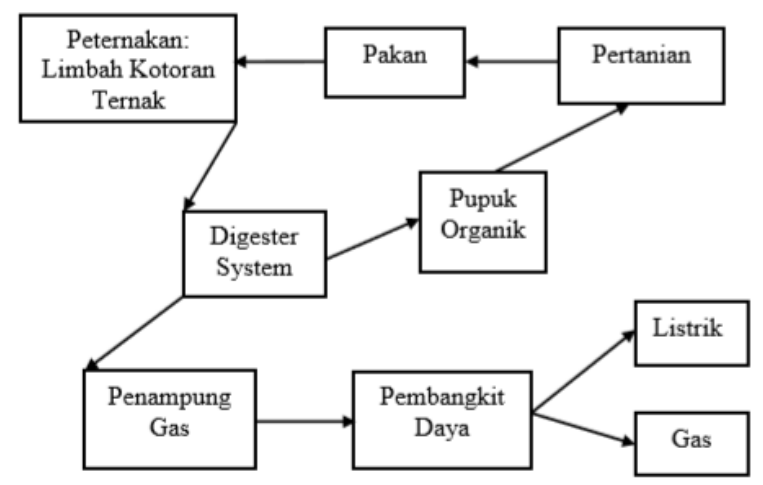

Gambar 2. Alur Produksi Biogas dan Pemanfatannya

Program DME yang dikembangkan di Desa Haurngombong menitikberatkan pada konsep pemberdayaan masyarakat untuk membangun kemandirian masyarakat dengan mengedepankan aspek partisipati warga masyarakat dalam setiap tahapan pelaksanaan program. Tahap pertama dalam pengembangan Program DME adalah proses penyampaian informasi. Pada tahap ini, Pemerintah Desa mengadakan musyawarah desa yang melibatkan para tokoh masyarakat, masyarakat peternak dan masyarakat secara keseluruhan untuk menyamakan persepsi mengenai rencana pengembangan Program DME. Tahap kedua adalah sosialisasi kegiatan yang bertujuan untuk memperkuat pemahaman mengenai Program DME sekaligus sebagai sarana berbagi ilmu pengetahuan dan informasi seputar teknologi instalasi biogas yang akan dipergunakan. Kegiatan sosialisasi yang diperuntukan bagi masyarakat desa, khususnya bagi peternak ini melibatkan pihak LiBEC UNPAD sebagai fasilitator. Tahap ketiga yaitu penyuluhan seputar teknologi biogas untuk memberikan pemahaman kepada masyarakat tentang teknik pembuatan, pengelolaan, pemeliharaan dan pemanfaatan instalasi biogas.

Tahap keempat adalah kegiatan pelatihan demonstrasi pembangunan instalasi biogas. Kegiatan ini lebih difokuskan untuk pengurus kelompok ternak sebagai calon pengelola instalasi biogas utama karena memiliki akses langsung dengan bahan baku biogas yaitu limbah kotoran ternak. Tahap kelima yaitu replikasi dalam kelompok. Pada tahap ini pengurus kelompok ternak yang sudah dilatih diberikan kesempatan untuk mengaplikasikan keterampilannya dihadapan anggota kelompok ternak dan masyarakat lainnya. Hal ini dimaksudkan untuk memunculkan jiwa kemandirian dalam diri pengurus kelompok dan memperkuat interaksi social antara kelompok dan masyarakat. Tahap keenam adalah pendampingan. Kegiatan pendampingan dilaksanakan untuk merespon feedback yang ada di masyarakat setelah kegiatan pelatihan dan replikasi kelompok. Tahap terakhir yaitu pelatihan manajemen pengelolaan keuangan. Kegiatan ini bertujuan untuk memberikan pemahaman dasar mengenai pembukuan sederhana, dan pengelolaan keuangan bagi pengurus kelompok untuk menunjang pelaksanaan Program DME.

Penjelasan informan tersebut menegaskan bahwa upaya pemberdayaan dalam pelaksanaan Program DME di Desa Haurngombong sudah bersifat spesifik. Tahapan-tahapan pelaksanaan Program DME yang dijalankan merupakan suatu proses pembinaan berkelanjutan yang terarah dan ditujukan untuk membangun kemandirian masyarakat dalam pengelolaan program tersebut. Wilson dalam bukunya "The Empowerment Mannual" menegaskan bahwa pemberdayaan meliputi tahap penyadaran (awakening), pemahaman (understanding), pemanfaatan (harnessing) dan penggunaan keterampilan 
( using). Tahapan awal dalam pelaksanaan Program DME berupa penyampaian informasi yang dilaksanakan secara musyawarah merupakan wujud upaya Pemerintah Desa untuk menumbuhkan kesadaran masyarakat dengan membangun landasan-landasan pikir untuk mengubah budaya masyarakat dalam pemanfaatan energi konvensional dalam bentuk minyak tanah dan elpiji menjadi pengguna energi alternatif biogas.

Pada pelaksanaan kegiatan penyuluhan dan pelatihan, masyarakat diberikan pemahaman, pengetahuan dan keterampilan mengenai teknik pembuatan dan pemeliharaan instalasi biogas, serta pemanfaatan gas yang dihasilkan. Tahap ini meliputi proses pembelajaran terhadap program untuk secara utuh sehingga diharapkan pada tahap selanjutnya yakni tahap replikasi kelompok masyarakat para peternak khususnya dapat memanfaatkan keterampilannya secara utuh baik untuk kepentingan pribadi maupun untuk juga turut melakukan pelatihan kepada masyarakat. Tahap terakhir yaitu tahapan penggunaan keterampilan atau dikenal juga sebagai tahap pembiasaan dimana masyarakat sudah mampu dan berdaya untuk mengelola dan memanfaatkan instalasi biogasnya secara mandiri dalam kehidupan sehari-hari.

Dengan memperhatikan arah keberpihakan yang tercermin dalam sasaran dan target program, serta adanya tahapan yang jelas dan spesifik selama pengembangan program maka dapat disimpulkan bahwa kegiatan pelaksanaan Program pemberdayaan masyarakat DME di Desa Haurngombong telah terlaksana secara terarah.

\subsection{Analisis Strategi Pelaksanaan Program Desa Mandiri Energi}

Penting bagi Pemerintah Desa untuk menyusun strategi dan kebijakan dalam melaksanakan tugas dan fungsinya sebagai penyelenggara pemerintahan di desa. Strategi yang disusun harus dapat menyentuh aspek-aspek strategis dalam masyarakat. Analisa SWOT merupakan instrument yang dapat digunakan untuk mengidentifikasi dan menganalisis faktor-faktor internal dan eksternal secara sistematis untuk merumuskan isu-isu strategis dalam penyelenggaraan pemerintahan. Penggunaan analisa SWOT dalam penelitian ini untuk memahami kekuatan (strength), peluang (opportunities), kelemahan (weekness) dan ancaman (threats) dalam pelaksanaan Program DME di Desa Haurngombong.

\subsubsection{Kekuatan (Strength)}

1. Ketersediaan bahan baku biogas yang melimpah Sektor peternakan merupakan salah satu sektor unggulan di Desa Haurngombong. Populasi ternak sapi perah berdasarkan data per Oktober 2011 berjumlah 1024 ekor dengan rata-rata tiap peternak memiliki 2-4 ekor sapi perah. Tingginya populasi ternak merupakan potensi kekuatan yang dimiliki desa guna menjamin keberlangsungan dan keberlanjutan program DME di Desa Haurngombong karena jumlah ternak yang banyak menghasilkan dapat limbah kotoran sapi yang melimpah sebagai bahan baku biogas.

2. Kondisi sumberdaya manusia yang mumpuni Jumlah peternak di Desa Haurngombong sangatlah besar yaitu mencapai angka 27,4\% dari total penduduk. Secara umum para peternak yang tergabung dalam ketiga Kelompok Ternak Sapi Perah Desa Haurngombong memiliki pengetahuan dan keahlian yang cukup mumpuni dalam pengelolaan instalasi biogas.

3. Peran aktif kelompok ternak sapi perah yang tinggi

Ketiga kelompok ternak sapi perah di Desa Haurngombong secara stimultan berperan aktif dalam upaya pemberdayaan anggota dan masyarakat. Pembinaan dan pelatihan yang dilakukan pengurus kelompok tenak hingga saat ini masih berjalan. Kegiatan supervisi yang dilakukan melalui pertemuan rutin antara anggota kelompok untuk memotivasi anggota untuk terus mengelola dan memelihara instalasi biogas yang mereka miliki. Apabila diperlukan, bagi keluarga non peternak pengurus ternak membuka kesempatan untuk melakukan dialog terkait program DME.

\subsubsection{Kelemahan (Weekness)}

1. Terbatasnya jangkauan instalasi biogas Pemanfaatan instalasi biogas di Haurngombong saat ini masih terbatas pada keluarga peternak sapi perah dan keluarga peternak non sapi perah yang rumahnya berdekatan dengan instalasi biogas keluarga peternak. Hal tersebut dikarenakan adanya keterbatasan pipa yang menghubungkan instalasi biogas ke rumahrumah. Hal tersebut menyebabkan 


\begin{tabular}{|c|c|c|c|c|}
\hline Share: Social Work Jurnal & VOLUME: 9 & NOMOR: 2 & HALAMAN: $130-141$ & $\begin{array}{c}\text { ISSN: 2339-0042 (p) } \\
\text { ISSN: 2528-1577 (e) } \\
\text { Doi: } 10.24198 / \text { share.v9i2.21015 }\end{array}$ \\
\hline
\end{tabular}

pemanfaatan biogas ini sendiri belum menjangkau seluruh lapisan masyarakat Desa Haurngombong.

2. Keterbatasan modal pembiayaan instalasi genset biogas

Instalasi biogas dapat menghasilkan energi gas berupa biogas dan dapat pula dialirkan pada genset untuk menghasilkan listrik. Sampai saat ini pemanfaatan biogas sebagai bahan pembangkit listrik masih sangat terbatas.

\subsubsection{Peluang (Opportunities)}

1. Besarnya apresiasi pihak luar terhadap program DME

Semenjak Desa Haurngombong mendapatkan penghargaan dari Kementerian ESDM sebagai Desa Mandiri Energi Terbaik pada tahun 2009, banyak pihak luar yang memberi apresiasi terhadap pengembangan DME di Desa Haurngombong. Sebagai salah satu wujud apresiasi Kementerian ESDM, pada tanggal 19 Agustus 2010, Menteri ESDM Darwin Saleh melakukan Kunjungan Kerja (Kunker) ke Desa Haurngombong. Sejak kunjungan tersebut, Desa Haurngombong menjadi desa percontohan DME dan mendapatkan kunjungan dari banyak daerah lain yang ingin mengembangkan potensi sumber daya energi biogas.

\section{Sejalan dengan kebijakan diversifikasi energi}

Pasal 20 ayat 1 Undang-Undang Nomor 30 Tahun 2007 tentang Energi mengamanatkan bahwa penyediaan energi dilakukan melalui diversifikasi, konservasi, dan intensifikasi sumber energi dan energi. Diversifikasi energi sendiri didefinisikan sebagai penganekaragarnan pemanfaatan sumber energi.

Diversifikasi energi adalah program yang diutamakan oleh pemerintah, terutama pengembangan energi terbarukan atau energi. Program DME termasuk salah satu program diversifikasi energi yang menyokong penyediaan energi daerah. Program tersebut adalah DME berbasis Bahan Bakar Nabati (BBN) dan Non BBN. Energi jarak pagar, kelapa, sawit singkong dan tebu digunakan sebagai bahan baku utama DME berbasis BBN menggunakan sedangkan mikrohidro, angin, surya, biogas dan biomassa sebagai sumber energi setempat untuk DME berbasis non-BBN. Dengan demikian, pencanangan program DME di Desa Haurngombong sejalan dengan program kebijakan pemerintah nasional dan diharapkan dengan adanya kesamaan visi dan misi kebijakan pemerintah dapat turut mensukseskan program DME ini.

\subsubsection{Ancaman (Threats)}

1. Tingginya biaya pemeliharaan ternak Pemilihan dan intensitas pemberian pakan ternak sapi perah merupakan wajib diperhatikan para peternak. Pakan ternak sapi perah terdiri dari hijauan dan konsentrat. Hijauan dapat berupa jerami, daun tebu, lamtoro atau rumputrumputan. Pakan Hijauan biasanya diberikan pada siang hari setelah pemerahan sedangkan pakan konsentrat diberikan dua kali sehari pada pagi dan sore sebelum sapi diperah.

2. Kenaikan harga daging sapi

Naiknya harga daging sapi potong hingga mencapai harga Rp. 100.000 menimbulkan kekhawatiran pengurus ternak sapi perah Desa Haurngombong. Banyak pengusaha yang sudah beralih untuk mencari keuntungan instan dengan menjual ternak sapinya. Hal ini membahayakan keberlangsungan program DME di Desa Haurngombong yang bertumpu pada pemanfaatan limbah kotoran sapi sebagai bahan baku biogas.

3. Rendahnya harga susu segar (fresh milk) Susu segar (fresh milk) merupakan komoditas utama para peternak sapi perah. Penurunan harga susu segar membawa dampak yang signifikan bagi kesejahteraan para peternak. Harga susu sapi segar di Jawa Barat per April 2014 seharga Rp 4.000.10 Harga tersebut masih berada dibawah Rp. 5.000 menyebabkan adanya defisit pendapatan. Hal ini dikhawatirkan mengurangi minat para peternak untuk melanjutkan usahanya dan menjual ternaknya. Apabila terjadi penurunan jumlah sapi perah sebagai produsen bahan baku biogas maka keberlangsungan program DME di Desa Haurngombong terancam. 


\begin{tabular}{|c|c|c|}
\hline Faktor & $\begin{array}{l}\text { Kekuatan (S) } \\
\text { 1. Ketersediaan bahan } \\
\text { baku biogas yang } \\
\text { melimpah } \\
\text { 2. Sumber daya manusia } \\
\text { yang mumpuni } \\
\text { 3. Peran aktif kelompok } \\
\text { ternak sapi perah yang } \\
\text { tinggi }\end{array}$ & $\begin{array}{l}\text { Kelemahan (W) } \\
\text { 1. Terbatasnya jangkauan } \\
\text { instalasi biogas } \\
\text { 2. Keterbatasan modal } \\
\text { instalasi genset }\end{array}$ \\
\hline $\begin{array}{l}\text { Peluang (O) } \\
\text { 1. Besarnya apresiasi } \\
\text { pihak luar terhadap } \\
\text { program } \\
\text { 2. Sejalan dengan } \\
\text { Kebijakan } \\
\text { Diversifikasi Energi } \\
\text { Nasional }\end{array}$ & $\begin{array}{l}\text { Strategi SO } \\
\text { 1. Pengembangan } \\
\text { ekonomi kreatif } \\
\text { 2. Meningkatkan mutu } \\
\text { biogas }\end{array}$ & $\begin{array}{l}\text { Strategi WO } \\
\text { 1. Meningkatkan } \\
\text { kerjasama dengan } \\
\text { pihak luar program } \\
\text { 2. Meningkatkan } \\
\text { manajemen usaha } \\
\text { ternak }\end{array}$ \\
\hline $\begin{array}{l}\text { Ancaman (T) } \\
\text { 1. Tingginya biaya } \\
\text { pemeliharaan ternak } \\
\text { 2. Kenaikan harga } \\
\text { daging sapi } \\
\text { 3. Rendahnya harga } \\
\text { susu segar (fresh } \\
\text { milk) }\end{array}$ & \begin{tabular}{l}
\multicolumn{1}{c}{ Strategi ST } \\
1. Pengembangan \\
teknologi instalasi \\
biogas \\
2. Penguatan anggota \\
peternak dengan \\
kelompok
\end{tabular} & $\begin{array}{l}\text { Strategi WT } \\
\text { 1. Memasyarakatkan } \\
\text { biogas sebagai energi } \\
\text { alternative } \\
\text { 2. Memanfaatkan jasa } \\
\text { kredit perbankan dalam } \\
\text { pengembangan } \\
\text { program }\end{array}$ \\
\hline
\end{tabular}

Gambar 3. Matriks SWOT program Desa Mandiri Energi (DME) di desa Haurngombong Sumber: Skematisasi Pribadi

\section{Kesimpulan}

Program DME di Desa Haurngombong, Kecamatan Pamulihan, Kabupaten Sumedang, Jawa Barat diterapkan melalui pemberdayaan masyarakat. Hasil analisis dimensi upaya terarah, keterlibatan kelompok sasaran, dan pendekatan kelompok menunjukan bahwa proses pemberdayaan masyarakat Program DME di Desa Haurngombong, Kecamatan Pamulihan, Kabupaten Sumedang, Jawa Barat dinyatakan tercapai. Penting bagi Pemerintah Desa untuk menyusun strategi dan kebijakan dalam melaksanakan tugas dan fungsinya sebagai penyelenggara Program DME. Dari analisa yang dilakukan beberapa strategi yang direkomendasikan untuk keberlangsungan Program DME di Desa Haurngombong antara lain melalui upaya pengembangan ekonomi kreatif, upaya peningkatkan mutu biogas, upaya pengembangan teknologi instalasi biogas, upaya penguatan anggota peternak dengan kelompok, upaya peningkatkan kerjasama dengan pihak luar program, upaya peningkatkan manajemen usaha ternak, upaya pemasyarakatkan biogas sebagai energi alternatif dan menjalin kerjasama jasa kredit perbankan guna pengembangan program.

\section{Ucapan Terimkasih}

Riset ini dibiayai oleh Dewan Perwakilan Daerah (DPD) RI. Terimkasih kami sampaikan kepada Program Studi Ketahanan Nasional, Program Pascasarjana Universitas Indonesia.

\section{Referensi}

Aiman, Syahrul, Sunit Hendrana, dan Manaek Simamora. (2015). Indonesia Renewable Energy Report. New Delhi: APCTUNESCAP.

Aly, A., Elnokaly, A.,\& Mills, G. (2017). Mind the gap: methodology discussion of the extraction and analysis of pilot phase data to generate multiconfiguration household behavioural profiles. In: Proceedings of 33rd PLEA International Conference Design to Thrive, vol. IAl Sumiati.

Bryson, John M. (1999). Perencanaan Strategis untuk Organisasi Publik dan Nirlaba: Sebuah Panduan untuk Memperkuat dan Mempertahankan Prestasi Organisasi, rev. ed. San Fransisco: J ossey-Bass. 


\begin{tabular}{|c|c|c|c|c|}
\hline Share: Social Work Jurnal & VOLUME: 9 & NOMOR: 2 & HALAMAN: $130-141$ & $\begin{array}{c}\text { ISSN: 2339-0042 (p) } \\
\text { ISSN: 2528-1577 (e) } \\
\text { Doi: } 10.24198 / \text { share.v9i2.21015 }\end{array}$ \\
\hline
\end{tabular}

Hendra. (2014). Wawancara Penelitian Tesis. Senior Specialist II ADFAS, PT PLN Distribusi J awa Barat - Banten.

Ife, J im dan Frank Tesoriero. (2008). Community Development: Alternatif Pengembangan Masyarakat di Era Globalisasi. Yogyakarta: Penerbit Pustaka Pelajar.

Kartasasmita, G. (1997). Pemberdayaan Masyarakat: Konsep Pembangunan yang Berakar Pada Masyarakat. Surabaya: Bappenas.

Moeliono I, Suaradika P, Sumantri A, Suhardi WB. (1994). Parcipatory Rural Appraisal Berbuat Bersama Berperan Setara. Bandung: Studio Driya Media.

Moleong, L.J . (2004). Metode Penelitian Kualitatif. Bandung: Remaja Rosda Karya.

Nasdian, F.R. (2006). Pengembangan Masyarakat (Community Development). Bogor: Departemen Komunikasi dan Pengembangan Masyarakat, Fakultas Ekologi Manusia, Institut Pertanian Bogor.

Nejat, P., J omehzadeh, F., Taheri, M., Gohari, M., $\&$ Abd Majid, M. (2015). A global review of energy consumption, CO2 emissions and policy in the residential sector (with an overview of the top ten $\mathrm{CO} 2$ emitting countries). Renew. Sustain. Energy Rev, 43, 843-862.

Pearce, J ohn A dan Richard B Robinson. (1994). Suatu Pengantar: Management Strategi (terjemahan). Jakarta: Havarindo.

Peraturan Menteri ESDM No. 32 Tahun 2008 Tentang Penyediaan, Pemanfaatan, dan Tata Niaga Bahan bakar Nabati (Biofuel) sebagai Bahan bakar Lain.

Prasetyo, Yanu Endar dan Umi Hanifah. (2011). Pengorganisasian Masyarakat Desa Mandiri Energi Studi Kasus PLTMH di Desa Palakka, Kecamatan Maiwa, Kabupaten Enrekang, Sulawesi Selatan. Komunitas, 5,1, 71- 92.

Pusat Data dan Informasi Energi dan Sumber Daya Mineral Kementerian ESDM. (2012). Kajian Indonesia Energy Outlook. J akarta: Kementerian ESDM.

Qadi, S.A., Sodagar, B., \& Elnokaly, A. (2018). Estimating the heating energy consumption of the residential buildings in Hebron, Palestine. Journal of Cleaner Production, 196, 1292-1305.

Rangkuti, Freddy. (2001). Manajemen Persediaan, J akarta: PT. Raja Grafindo Persada

Sugiono, Agus. (2012). Pemberdayaan ekonomi masyarakat melalui pengembangan desa mandiri energi di kabupaten lampung selatan. Jurnal Bidang Perencanaan Energi, 50-58.

Suharto, E. (1997). Pembangunan, Kebijakan Sosial dan Pekerjaan Sosial: Spektrum Pemikiran. Bandung: Lembaga Studi Pembangunan-STKS.

Wang, R., dan Jiang, Z. (2017). Energy Consumption In China's Rural Areas: A Study Based On The Village Energy Survey. J. Cleaner Prod., 143.

Wei, S., Jones, R., de Wilde, P. (2014). Driving Factors For Occupant-Controlled Space Heating In Residential Buildings. Energy Build, 70, 36-44.

Yusgiantoro, P. (2000). Ekonomi Energi: Teori dan Praktek. Jakarta: LP3ES. 